\title{
THE SACRAMENT OF CONFIRMATION AND THE COMMON PRIESTHOOD OF BELIEVERS: THE STUDY OF THE RELATION WITH REGARD TO THE SPECIFIC CONTEXT OF THE CZECH AND SLOVAK CHURCHES
}

\author{
Z UZA NA MATISOVSKÁ
}

\begin{abstract}
The article asks a question about the link between the comprehension of believers of their common priesthood and the authentic place of confirmation within Christian initiation, enabling one to participate in the tria munera Christi. First of all, the author explains the role of the term, 'common priesthood' in the theology of the sacrament of confirmation and its origin in Christ, the only perfect High priest of the New Testament and in the priestly nature of his body, the Church as it is presented by the universal magisterial documents since the Second Vatican Council. This reality is manifested in unity and order of the Christian initiation. A following part describes how this feature has not been included in the Czech and Slovak instructions and episcopal documents and explores a local praxis. The unity of the three sacraments is understood in a superficial manner, and their order is underestimated or doubted in this area; however, pastoral needs and a link between confirmation and the age of adolescence is determining. In consequence, the faithful cannot perceive the signs referring to the reality of common priesthood and the effects of confirmation are reduced. The last part tries to answer the question what can be done to renew the authentic place of confirmation in local communities in order to enable believers to grasp their participation on Christ's threefold office in a better way.
\end{abstract}

\section{Key words}

Common Priesthood; Universal priesthood; Sacraments; Confirmation; Initiation; Magisterium; The Second Vatican Council

DOI: $10.14712 / 23363398.2020 .44$ 
The doctrine of the common priesthood is an essential element of contemporary sacramental theology and ecclesiology. Nevertheless, it remains unknown and rather abstract or theoretical for many faithful of Czech and Slovak regions, for laity as well as clergy. An enquiry of magisterial documents dealing with the sacrament of confirmation since the Second Vatican Council revealed undeniable differences between the approach present in the universal Magisterium and local episcopal instructions. ${ }^{1}$ While the concept of common priesthood is crucial for the theology of confirmation arising from universal magisterial texts, particular documents are more concerned with other aspects and sometimes prefer questionable or even contradictory practices.

I asked myself a question about the link between the comprehension of believers of their common priesthood and the authentic place of confirmation within Christian initiation, enabling one to participate in the tria munera Christi. In this article, I would like to show that if the sacrament of confirmation in the local communities were to occupy its proper place as described in the documents of the universal Magisterium, it would contribute to the ability of believers to better understand and live out their common priesthood.

I will approach the topic from the systematic perspective of sacramental theology; therefore, even though the theme includes some aspects which need to be expended by other theological disciplines, e. g. pastoral theology, it cannot be done properly in one article and I restrict myself to presenting particular theological principles, interconnections among them, and potential influence on practice.

First of all, I will explore the essential connection of the term common priesthood with Christian initiation and especially the sacrament of confirmation in the universal magisterial documents since the Second Vatican Council. Then, I will describe how this element has not been included in the Czech and Slovak instructions and episcopal texts and outline a local praxis. Finally, I will propose some possible steps which could return confirmation to its authentic place and so help the faithful to fully grasp their participation in Christ's threefold office today.

1 Cf. Zuzana Matisovská, 'Sviatost' birmovania - jej teologické pochopenie v partikulárnych dokumentoch a smerniciach (v ČR a SR) v porovnaní s jej teologickým pojatím vo všeobecných dokumentoch Magistéria od II. vatikánskeho koncilu po súčasnost' (Master's thesis, Charles University, Prague, 2019). 


\section{The Relation of the Sacrament of Confirmation and the Common Priesthood in the Universal Magisterial Documents since the Second Vatican Council}

The doctrine of the common priesthood of God's people was formulated on biblical bases in the works of patristic fathers but omitted by Catholic theologians as well as magisterial documents for a long time since the reformation controversies. One of the important aims of the Second Vatican Council was to renew a complex perspective on sacraments by emphasising their ecclesial dimension. The council fathers, discussing the role of lay people in the Church community, realised that the common priesthood is not an isolated theological task, but rather a key feature in understanding the nature of the whole Church continuing in Christ's ministry. ${ }^{2}$ Thus the doctrine of the Church and the sacraments is deliberately formed by Christology and soteriology. ${ }^{3}$

Christ as the High Priest ${ }^{4}$ and the unique Mediator is the cause of all New-Testament priesthood. The core of his works is worship aiming for the glory of the Father and the participation of the humanity in this divine life. He offers the only perfect sacrifice of his life throughout all his acts completed on the cross. However, its proper meritorious essence does not consist in the degree of the physical suffering but in the spiritual sacrifice - the act of his free will giving himself to the Father in love. ${ }^{5}$ Therefore, the Church being established as the sacrament of Christ and continuing in his work - a sign and instrument of salvation for all people - is defined as a priestly community bringing its nature into operation through the sacraments and virtues. ${ }^{6}$ The Church accepts the worship with a visible and invisible aspect as her proper function from Christ and his perfect sacrifice allows the whole community and all its members to be joined with their whole lives and participate in the history of salvation. Being a Christian is a direct and ontological sharing in Christ's priesthood ${ }^{7}$ and the dignity of 'a chosen

2 While at first the article dealing with the common priesthood was part of the chapter concerning the rights and obligations of lay people, it was later moved to the second chapter about the people of God. Cf. AS I/IV, p. 38. art. AS I/III, p. 183.

Cf. $L G$, chapters 1 and 2, especially art. 5, 9, 10.

Cf. Heb 5:1-5.

Cf. Thomas Aquinas, STh III. 22. 2.

Cf. $L G 11$.

Cf. $L G 34$. 
people, a royal priesthood and a holy nation'8 is constituted in every believer personally through the sacrament of baptism, confirmation, and the Eucharist. The process of initiation takes the central place in the conciliar view of the sacramental organism of the Church and each of the three sacraments is essentially related to the common priesthood in a specific manner. ${ }^{9}$ This relation is manifested in the unity and order of Christian initiation and is determinative for other pastoral issues.

\subsection{Unity}

Conciliar documents never deal with the sacrament of confirmation in isolation, but always in relation to baptism and the Eucharist. ${ }^{10}$ The unity of Christian initiation is based on the complementarity of the sacramental effects of these three sacraments. ${ }^{11}$ Conciliar and post-conciliar documents considerably deepened the doctrine about the sacramental character (res et sacramentum) in relation to the concept of the common priesthood. The character used to be generally defined as an indelible spiritual mark, but no detailed definition could be found in magisterial texts until then. ${ }^{12}$ Beginning with the council, the baptismal character has been described as a sign of belonging to Christ, an empowerment to Christian worship, sacrifice, and testimony and an assignment to sharing in the priestly, prophetic, and kingly mission of Christ. ${ }^{13}$ Two fundamental, distinct but interconnected, phases of the consecration must be recognised. ${ }^{14}$ While baptism allows participation in the common priesthood on a basic level, the effect of

81 Pt 2:9; Rev 6:1; 5:9-10.

9 The first scheme of Lumen gentium contained an appropriation of the three ministries of Christ to the individual sacraments of Christian initiation. It was later rejected and related to the initiation as a whole. Cf. $A S \mathrm{I} / \mathrm{IV}$, p. 45.

10 Cf. $S C 71 ; L G 9,10,11,33,34 ; A A 3, P O 5 ; A G 11,36 ; U R 22$.

11 Cf. CIC $842 \$ 2$.

12 A conciliar development of the doctrine can be observed in contrast with Roman catechism, which referred to the baptismal and confirmation character with no mention of common priesthood of all the baptised. Cf. Roman catechism II, 2, q. 41 and II, 3, q. 4. For some pre-conciliar authors describing confirmation as a new level of consecration and sharing in Christ's priesthood and mission cf. Bernard Leeming, Principles of Sacramental Theology, 2nd ed. (Westminster MD: Newman, 1960), 237; Max Thurian, Consecration of the Layman (Helicon: Baltimore, 1963), 83-94.

13 Cf. LG 11; AA3; Pope John Paul II, Christifideles laici, AAS, 81 (1989), art. 14, 23; CCC 1272-1274.

14 Cf. Pope Paul VI, Divinae consortium naturae, AAS, 63 (1971), p. 660; Ordo confirrmationis, Editio typica 1971, a. 1; Ordo Initiationis christianae adultorum, Reimpressio emendata 1974, art. 1-2; Congregation for the Clergy, Directorium catechisticum generale, AAS, 64 (1972), art. 57, 65, 66. 
confirmation, often expressed in comparison, is the special gift of the Holy Spirit imparting strength, perfection, and maturity. The one's bond with the Christ-head and the Church-body is made closer. ${ }^{15}$ Further distinguishing of the precise function of baptism and confirmation in the formation of the common priesthood is left to theological reflection, but the sacrament is often reported as necessary for the full growth of the spiritual life. ${ }^{16}$ On the other hand, the common priesthood, not confirmation alone, establishes the apostolate of the faithful. ${ }^{17}$ No additional mandate from a hierarchy is needed, as it is an essential feature of Christian existence implying multiple forms of realisation. ${ }^{18}$

The intimate connection of confirmation with the whole of Christian initiation as well as relationships among the three sacraments should be perceptible from the sacramental rites and their arrangement. ${ }^{19}$ Considering sacramentality, a firm link between the visible external sign and the invisible signified reality enabling grace to be

15 LG 11; Pope Paul VI, Divinae consortium naturae, AAS, 63 (1971), p. 657; CCC 1272-1274, 1285; Ordo Initiationis christianae adultorum, Reimpressio emendata 1974, art. 2.

16 The council consciously eliminated the term 'baptismal priesthood' which had appeared in preparation schemes as it darkens the necessity of confirmation for complete initiation and so, reduces the common priesthood to baptism alone. Cf. Benedikt Tomáš Mohelník, Gratia augmenti: Contribution au débat contemporain sur la confirmation (Fribourg: Academic Press Fribourg, 2005), 37. For underlined necessity of confirmation cf. UR 22; Ordo Initiationis christianae adultorum, Reimpressio emendata 1974, art. 2; CCC 1212, 1285, 1305; Pope John Paul II, Reconciliatio et paenitentia, $A A S, 75$ (1985), p. 248-250, art. 27; 'Meeting with the candidates of confirmation,' Pope Benedict XVI, published June 2, 2012, https://bit.ly/3j3VtdA.

17 The ability to bear a testimony throughout one's whole life has been connected to confirmation as its proper effect. Regarding the context where these terms are used, I suggest understanding testimony as a public declaration of Christian faith present in various situations of life, and apostolate rather as the active and intentional transmission of faith. Bernard Leeming points out that bearing a testimony and apostolate also arise from the participation on Christ's priesthood as he was the one mediator who offered the sacrifice of man to God as well as brought the truth of God to mankind. Cf. Bernard Leeming, Principles of Sacramental Theology (Westminster MD: Newman, 1960), 237.

18 Cf. $L G$ 31, 33; $A A$ 3; $A G$ 11, 36; CIC 759; Ordo confirrmationis, Editio typica 1971, art. 22; Česká biskupská konference, V̌seobecné direktorium pro katechizaci (Praha: Sekretariát České biskupské konference, 1998), art. 50, 231; Pope Benedict XVI, Sacramentum caritatis, AAS, 99 (2007), p. 165-167, art. 79; Pope Francis, Evangelii gaudium, AAS, 105 (2013), p. 1091, art. 1.

19 SC 71 appoints evident unity as the main criterion for the revision of the confirmation rite and Paul VI refers to it in the constitution. Cf. Pope Paul VI, Divinae consortium naturae, AAS, 63 (1971), p. 657. 
approached by faith cannot be avoided.$^{20}$ While in the case of adult catechumens, the unity of the Paschal mystery reflected in the ties among the sacraments of initiation is made evident through their conjoint celebration, ${ }^{21}$ a separate rite of confirmation also involves the renewal of baptismal vows, the proclamation of Creed, and should be included within a Eucharistic celebration. ${ }^{22}$

\subsection{Order}

The ultimate criterion for the order of Christian initiation and for further resolutions of pastoral issues is the central position of the Eucharist. ${ }^{23}$ The declaration of this key to understanding confirmation represents the culmination of the magisterial teaching continually emphasising the Eucharist as the source and summit of the life of the Church and of every Christian. ${ }^{24}$ We are baptised and confirmed towards the Eucharist. This means that by these two steps we are enabled (1) to actively join in the liturgical worship of the Church following Christ the priest offering himself to the Father, as well as (2) to live a eucharistic life as a whole-hearted offering of everyday acts of love as a sacrifice. ${ }^{25}$ The common priesthood formed in a person through the characters of baptism and confirmation can be subsequently perfectly realised in the Eucharist. The classical composition of the three sacraments - baptism, confirmation, and the Eucharist - is considered as the norm in magisterial documents as it correlates the most adequately with the main effect of the initiation process. Even though it is allowed to move the celebration of confirmation for serious reasons which are not precisely defined, and it is possible to receive

20 Cf. $S C 21,59$. Papal catecheses also explain the effects of the sacraments describing visible elements of the liturgy emphasising the bonds between baptism, confirmation and the Eucharist. Cf. 'Homily during Chrism mass,' Pope Benedict XVI, published April 21, 2011, https://bit.ly/30iw735; 'General audience on 30 May 2018,' Pope Francis, published May 30, 2018, https://bit.ly/3jbgnHS.

21 Cf. Ordo Initiationis christianae adultorum, Reimpressio emendata 1974, art. 36; CCC 1233.

22 Cf. Ordo confirmationis, Editio typica 1971, art. 5, 13; CCC 1233, 1298; CIC 881.

23 Cf. Pope Benedict XVI, Sacramentum caritatis, AAS, 99 (2007), p. 117-119, art. 16-18, p. 165-166, art. 79 .

${ }_{24}$ LG 11; PO 5; Pope Paul VI, Divinae consortium naturae, AAS, 63 (1971), p. 657; CIC 897; Pope John Paul II, Dominicae Cenae, AAS, 72 (1980), p. 124-128, art. 7; Ibid., Ecclesia in America, AAS, 91 (1999), p. 770, art. 35.

25 For division of the Christian worship into liturgical and non-liturgical cf. Benedikt Tomáš Mohelník, Gratia augmenti: Contribution au débat contemporain sur la confirmation (Fribourg: Academic Press Fribourg, 2005), 190-197. 
the Eucharist before the completed initiation and to celebrate the confirmation afterwards, ${ }^{26}$ this should be considered as an unsatisfactory exception expressing the essential logic of the Christian initiation with deficiency.

\section{The (Mis)understanding of the Relation in the Local Instructions of Czech and Slovak Dioceses}

The goal of instructions declared by episcopal conferences or individual bishops for particular dioceses is usually not to cover a matter exhaustively but to offer adequate rules for the specific local conditions. However, a view of the sacrament of confirmation presented in the Czech and Slovak environment is often overly reduced and misses the basic elements crucial for assessing suitable pastoral processes. Although all of the current documents ${ }^{27}$ came into existence a long time after the council, the term, 'common priesthood' holds a marginal place in them and is mentioned only indirectly. Its fundamental role for the meaning of confirmation and the whole process of sacramental initiation has not been included. An approach promoted in communities of this area apparently corresponds in terminology or in certain aspects, but without a clear recognition of their meaning and theological foundations, the understanding of the sacrament needed for a competent differentiation is superficial. Local instructions and episcopal sermons often mention the unity of initiation, remind the people of the importance of confirmation for the completion of initiation, and even name the three sacraments in classical order, ${ }^{28}$ but they miss the

26 Cf. Ordo Initiationis christianae adultorum, Reimpressio emendata 1974, art. 34-35, 46, 56, 304; Ordo confirmationis, Editio typica 1971, art. 11.

27 Referring to the Czech Republic, an up-to-date instruction dealing with the sacrament of confirmation has been formed in the archdioceses of Prague and Olomouc and in the diocese of Brno. A report of the diocesan pastoral centre in Hradec Králové states in 2008 that confirmation is not an issue for local priests and pastoral workers these days. The only instruction in the diocese of Litoměřice created in 1998 and containing a list of prayers compulsory for every recipient was completed in 2009 with a request for the personal testimony of faith to be examined by the bishop. Concerning the Slovak region, an instruction exists in Košice, Nitra and Banská Bystrica. A synodal document of the diocese of Spiš from 2011 as well as a circular letter from 2016 in diocese of Rožňava briefly sums up the basic guidance of the Episcopal conference concerning the minimum age and the length of preparation.

28 Cf. $A C A C$ 2/1997; $A C A P$ 4/2006; 'Smernice pre katechetickú prípravu k sviatostiam Eucharistie a birmovania,' Alojz Tkáč, published November 30, 2006, https://bit .ly/3eEeD6m; ACEN 1/2009; Biskupský úrad Spišská kapitula, Dokumenty Druhej 
theology of the common priesthood that lies behind these features as well as some other essential themes which form the background to the perspective of confirmation as presented by the universal Magisterium (e.g. the context of salvation history or the theology of the divine missions, explaining the relation between Theology and Economy). Thus, they prefer pastoral reasons to be definitive in important tasks and cannot sustain the coherence of practice. Bishops, recognising certain pastoral needs, ${ }^{29}$ are often not able to adequately discern their link to the sacrament of confirmation. This state is theologically chaotic, pastorally unsustainable, and evidently ineffectual. ${ }^{30}$ The fact that the concept of the common priesthood has not been incorporated leads to a disruption of the unity and order of initiation and the inability of believers to understand the meaning of the sacrament of confirmation. I will illustrate this below with two examples.

\subsection{Confirmation as the Sacrament of Adolescents}

First, universal magisterial documents refer to the age of reason as the normative age for confirmation, ${ }^{31}$ but other options are not excluded as well. ${ }^{32}$ Czech and Slovak episcopal conferences generally set a higher age, intending to make provision for pastoral needs. Setting the minimum age of confirmation to thirteen years of age in the Slovak Republic and at fourteen years of age at the Czech Republic ${ }^{33}$ does not involve a change of the order necessarily, but this is exactly what happened in all local dioceses as the conferences at the same time support the celebration of the First Holy Communion of children reaching the

synody Spišskej diecézy (Námestovo: Tlačiareň Kubík, 2011), 29, 46; ACAP 9/2012; 'Velikonoční pastýřský list,' František Václav Lobkowicz, published April 8, 2012, https://bit.ly/2ZxaTzg; ACEB 10/2015; Česká biskupská konference, Dokument o smérováni katecheze a náboženského vzdèláváni v České republice (Praha: Česká biskupská konference, 2015), art. 25, 54, 56.

29 For example, growth in maturity of the faith allowing one to bear witness to and be an active member of the community; the provision of pastoral care for the youth and other groups of faithful; the substitution of a lack of formation with respect to the complexity of the human person; supporting the relationship between a member of the faithful and his bishop.

30 Cf. Gerard Austin, Anointing With the Spirit: The Rite of Confirmation (Minnesota: Liturgical Press Collegeville, 1985), 128.

31 Cf. CIC (1983), can. 97; CCC 1307.

32 Cf. CIC (1918), can. 788; CIC (1983), can. 891; Ordo confirmationis, Editio typica 1971, art. 11.

33 Cf. BK ČSFR 5-17/10. - 11. 10. 1990; Konferencia biskupov Slovenska, Vyhlásenia a rozhodnutia Konferencie biskupov Slovenska (Trnava: Spolok sv. Vojtecha, 2015), 29. 
age of reason. This questionable change is not reflected in the particular instructions at all. In the case of people who are baptised soon after birth, confirmation is celebrated a long time after their baptism and First Holy Communion and it is tightly joined to the age of adolescence and advanced catechesis of teenagers, reminding them of their need to personally declare the faith they received from their parents. In this way, the process of the gradual constitution of the common priesthood reaching its peak in the Eucharist cannot be recognised.

\subsection{Reasons for Postponing Confirmation in the Case of the Initiation of Adults}

Secondly, with respect to the emphasis of universal documents, there are three reasons particularly mentioned in some instructions as insufficient for postponing confirmation in the case of adult catechumens: repeated meetings with a bishop, insufficient preparation for confirmation while one seems to be prepared for the Eucharist, and an attempt to prolong the period of catechesis. ${ }^{34}$ The demand is based on an awareness of the unity and complementarity of initiation as well as the Eucharist as its summit. There is no reason to abandon this as a priority - neophytes should continue in catechesis during the period of mystagogy where there are many opportunities to build a relationship with their bishop, not to mention the fact that if a catechumen is not prepared to receive confirmation, he is not prepared to receive the Eucharist as well. Nevertheless, all these reasons are declared as relevant in the archdiocese of Olomouc and are followed as the norm. ${ }^{35}$ The sacrament of confirmation is presented as the final step requiring more catechesis and natural maturity than the Eucharist itself.

\section{The Sacrament of Confirmation Today}

The question is what can be done to renew the authentic place of confirmation in local communities in order to enable believers to better perceive and live out of their common priesthood and the grace they received through initiation. I would like to offer four points arising from my systematic research of magisterial documents:

\footnotetext{
34 Cf. $A C A P$ 4/2006; $A C A P$ 9/2012; the emphasis on unity also in $A C A C 2 / 1997$, art. 4; 'Smernice pre katechetickú prípravu dospelých,' Alojz Tkáč, published November 30, 2006, https://bit.ly/2Zy8HYg.

35 Cf. $A C A O 1 / 1997 ; A C A O 5 / 2010 ; A C A O 4 / 2014$.
} 


\subsection{Integrating Development of the Doctrine}

Particular documents dealing with the sacrament of confirmation should include the evolved doctrine of both the priestly nature of the Church and of every believer's participation in Christ's priesthood, which is underlined in the teaching on initiatory sacramental characters. Despite the noticeable development and emphasis present in the universal magisterial documents, Czech and Slovak instructions remain static or arise exclusively from local pastoral needs. Only a more complex approach including the essential theological features (biblical context, sacramental sign, character, and grace) can lead to the truthful differentiation among the needs which ought to be covered in the context of pastoral praxis connected with confirmation and those requiring different solutions. ${ }^{36}$ Doctrine is meant to be rooted in the life of communities so it can authentically develop in dialogue with changing historical circumstances and bear the fruit of salvation in concrete human lives. The sacrament of confirmation is not an isolated ceremony. It is defined by its place within the initiation process constituting the common priesthood and should not be manipulated in order to reach different goals contradicting the visibility of this relation. Contemporary experience paradoxically proves that an approach completely based on pastoral reasons is not only theologically confusing, but also pastorally ineffectual. ${ }^{37}$

\subsection{Restoring the Classical Order of Initiation}

Pope Benedict XVI turned attention to the order of initiation and reminded the importance to evaluate

which practice better enables the faithful to put the sacrament of the Eucharist at the centre, as the goal of the whole process of initiation. In close collaboration with the competent offices of the Roman Curia, Bishops'

36 Andrzej Megger describing a similar situation in Polish environment speaks about the common floundering about the essence of confirmation reflected in reducing and incoherent pastoral praxis. 'The deepening of the theology of the sacrament of confirmation appears to be a necessary prerequisite to look for concrete pastoral solutions.' Andrzej Megger, 'Confirmation - Is It Still the Sacrament of Christian Initiation?’ Łódzkie Studia Teologiczne 26, no. 2 (2017): 174, 182.

37 The fact that confirmation is infamously known as 'a sacrament of farewell' is often mentioned by Pope Francis. Also cf. e. g. Maria Campatelli, Křest (Olomouc: Refugium Velehrad-Roma: The Liturgical Press, 2010), 114-115. 
Conferences should examine the effectiveness of current approaches to Christian initiation. ${ }^{38}$

The classical order - baptism, confirmation, and the Eucharist - depicts the meaning of the process, makes the order of grace more understandable, and the common priesthood less abstract and more likely to be integrated into everyday life.

Nothing hinders the restoration of the classical order in the case of adult catechumens, but different solutions are worth consideration as well in the case of people baptised soon after birth. One of the possibilities is to confer confirmation before First Holy Communion at the age of reason, that is approximately at seven years of age. The most often expressed argument doubting this practice is that confirmation as the sacrament of Christian maturity ought to be received by people taking full responsibility for their acts and expressing their free acceptance of the faith, in which they were baptised. The ideal time for this seems to be the age of adolescence. ${ }^{39}$ It is true that a coming-of-age ritual would be beneficial in many perspectives nowadays, but regarding the view of confirmation in universal documents after the council, confirmation should not take its place. ${ }^{40}$ St. Thomas Aquinas, in developing the analogy of growth in the natural and supernatural order, clearly

38 Cf. Pope Benedict XVI, Sacramentum caritatis, AAS, 99 (2007), p. 119, art. 18. Paul Turner labels the document as an advancement in understanding of confirmation in comparison with the report from the assembly of American bishops in 1998 dealing with the task of age of confirmees. Joseph Ratzinger, that time prefect of the CDF, claimed there that the time had not yet come to set the explicit key for understanding confirmation. Cf. Paul Turner, 'Benedict XVI and the sequence of the sacraments of initiation,' Worship 82, no. 2 (March 2008): 132-140.

39 Andrzej Megger recognizing the magisterial teaching of the last decades concludes that referring to confirmation as the sacrament of Christian maturity is inappropriate because it should be administered at the beginning of Christian life, it conditions further development and the process of initiation is completed by the Eucharist. Cf. Andrzej Megger, 'Confirmation - Is It Still the Sacrament of Christian Initiation?' Łódzkie Studia Teologiczne 26, no. 2 (2017): 182-185. In my opinion, the term maturity can be used if interpreted adequately - there are two phases constituting a mature Christian being on the supernatural level through the sacramental characters of baptism and confirmation, which can be subsequently fully active bringing sacrifice of everyday life summiting in the Eucharistic celebration.

40 Cf. Peter E. Fink, The New Dictionary of Sacramental Worship (Minnesota: The Liturgical Press, 1990), 610. See also Richard J. Barnier who concludes that 'confirmation is not a Catholic Bar Mitzvah' Richard J. Barnier, 'The Sacrament of Confirmation in Roman Catholic Tradition: A History of Interpretations and Proposal for Integration,' (PhD diss., McGill University, Montréal, 2014), 258. 
declares that maturity in the order of grace is of a different character than biological adulthood. ${ }^{41}$ The effect of grace is always connected with a development of natural human abilities ${ }^{42}$ and reaching a certain mental and social capacity is normally required as a condition to receive the sacrament, but confirmation is still first of all a gift by which God himself forms one into a complete Christian being ${ }^{45}$ and gives one a participation in Christ's priesthood. In the Catholic Church, confirmation has never been primarily understood as a ceremony of personal acceptance of faith by an adult individual in front of a community.

It is around the age of seven when people are gradually able to discern good from evil and voluntarily enter into relationships. Therefore, at this time when they are also competent to receive the Eucharist for the first time, they need to be enabled on supernatural level to receive a full participation in Christ's threefold office as king, prophet, and priest. The grace of confirmation would empower them to give every act as a sacrifice to God. In this way, even a child can slowly learn to build a relationship with God set in the context of everyday life. If there are serious reasons why this is not possible or adequate, the postponing of First Holy communion should be considered as well.

\subsection{Distinguishing a Pre-sacramental Catechesis from a Permanent Catechesis}

Pre-sacramental catechesis is treated in many Czech and Slovak dioceses as the unique chance to evangelise and educate young people, and in this way, to prevent their departure from the church community. Pre-sacramental catechesis is therefore often overly extended and covers multiple areas of Christian theory and practice, while the essential elements of confirmation including the concept of the common priesthood are neglected. Therefore, it is important to differentiate between the immediate preparation for the sacrament and continual catechesis, which is a permanent feature of Christian life, in order to determine an adequate content of the pre-sacramental catechesis. While the so-called preparation for Christian life is a rather constant process of spiritual accompaniment on many levels regarding the special needs of various groups of the faithful, immediate preparation aims to support

${ }^{41}$ Cf. Thomas Aquinas, STh III. 72. 8 ad. 2.

42 Cf. Thomas Aquinas, STh I. 1. 9.

43 This interpretation of Aquinas' teaching is included in the Catechism of the Catholic Church. Cf. CCC 1308. 
the capability of a person to fruitfully receive a sacrament. It presupposes a proper spiritual and moral disposition, adequate knowledge about the meaning of the sacrament, its place in the context of Christian doctrine, and the identification of the basic forms of living out of the sacramental grace. The teaching about the common priesthood, implying its practical realisation in various stages of life, should have a major place within both types of formation, but in a particular manner within the pre-sacramental formation period.

It must be clear that not everything is completed before the celebration of initiation, and local authorities ought to decide which elements are going to be included in the following period of mystagogy as well as look for the concrete ways to incorporate the newly-initiated into a particular community, where different types of permanent formation should be present as a normal and necessary part of the Christian life. The period of mystagogy which returned to the universal magisterial texts due to the conciliar liturgical reform as one of the four necessary stages of Christian initiation ${ }^{44}$ is accepted in theory by particular instructions ${ }^{45}$ but put into practice only to a minimal extent. The shift of the emphasis from the pre-sacramental catechesis to the mystagogy would represent a required change in the approach respecting the proper place of confirmation and underlining the importance of lifelong formation for continual development of the ability to live out of the common priesthood in changing life circumstances.

\subsection{Wider Approach to the Effects of Confirmation}

St. Thomas Aquinas repeatedly says that the main effect of confirmation is the fulness of the Holy Spirit, which means the plenitude of grace making us to the likeness of Christ. ${ }^{46}$ Particular documents attempting to define specific effects of confirmation respect this distinct pneumatic character of the sacrament, following the universal magisterial texts. Nevertheless, as they understand the term 'Christian adulthood' in a manner which is overly dependent on biological and

${ }_{44}$ Cf. SC 64, 66; Ordo Initiationis christianae adultorum, Reimpressio emendata 1974, art. 7, 37-40.

45 Cf. Česká biskupská konference, Dokument o smérováni katecheze a náboženského vzdẻláváni v České republice (Praha: Česká biskupská konference, 2015), art. 13-27; ACAP 4/2006; ACAP 9/2012; Jan Graubner, 'K roku biřmování. Pokus o hodnocení zkušenosti,' Teologické texty 23, no. 3 (2012); ACEB 10/2015, art. 20; ACAC 2/1997.

46 Thomas Aquinas, STh III. 72. 
psychological maturity, they tend to emphasise the readiness of the recipient to accept responsibility and concrete apostolic activities in a church community. ${ }^{47}$ The effects of confirmation in relation to the Eucharist are completely missed, which can be associated with an underestimating of the term 'common priesthood' and the order of initiation.

According to Mohelník, 'a narrow approach to Christian worship is the dominant factor limiting elaboration of the theology of confirmation based on the concept of the common priesthood'. ${ }^{48}$ The sacraments of the New-Testament have the two main functions - the sanctification of a man through healing him of the corruption due to sin (gratia sanans) and perfection of his abilities to perform worship (gratia elevans).$^{49}$ Confirmation enables a Christian to offer all that he is and everything he does - every act of love, in every age and state of life as a sacrifice ${ }^{50}$ - and so accomplish perfectly his common priesthood. Worship is not to be realised exclusively as a concrete service within a parish but in a common life, personal roles, a family, and in the secular world among other people. Every Christian following Christ is called to be a gift for others - as a priest, prophet, and king. He or she is empowered by the Holy Spirit to transform every environment and situation through his or her active approach - theological love, and virtues. ${ }^{51}$ In the power of their common priesthood, the faithful are able to join all this to the perfect sacrifice of Christ, which is made present in the Eucharist and subsequently vivifies them with the divine grace of the Holy Spirit and connects them with the Father. This way,

${ }_{47}$ Daniel G. Van Slyke criticises reduced approach preferring 'activist anthropological and psychological starting point' of understanding confirmation as a main criterion for its postponing to the age adolescence. Cf. Daniel G. Von Slyke, 'Confirmation - A Sacrament in Search of a Theology?' New Blackfriars 92, no. 1041 (September 2011): 24-29.

48 Cf. Benedikt Tomáš Mohelník, Gratia augmenti: Contribution au débat contemporain sur la confirmation (Fribourg: Academic Press Fribourg, 2005), 109.

49 Cf. e.g. Thomas Aquinas, STh III. 60.5 corp.; Ibid. Sth III. 63. 1, corp; Thomas Aquinas, O svátostech v Teologické sumé (Překlad, úvodní studie a poznámky Benedikt Mohelník OP, Praha: Krystal OP, 2019), 45-47; SC 59.

50 Augustine defines the true sacrifice as 'every act which is designed to unite us to God in a holy fellowship, every act, that is, which is directed to the final Good which makes possible our true felicity'. Cf. De Civitate Dei 10. 6.

51 Cf. $L G$ 34: 'For all their works, prayers and apostolic endeavours, their ordinary married and family life, their daily occupations, their physical and mental relaxation, if carried out in the Spirit, and even the hardships of life, if patiently borne-all these become "spiritual sacrifices acceptable to God through Jesus Christ".' 
the Eucharist is the source and summit of one's whole life approached through his or her common priesthood. The effect of confirmation is here essential and recognising its real contribution would help to see propriety of the classical order. ${ }^{52}$

\section{Conclusion}

I am aware of the fact that all the proposed suggestions require further elaboration and need to be transformed into detailed pastoral practices regarding the specific conditions of particular communities and participating individuals, but I believe that I have clearly shown that there is a close relation between the sacrament of confirmation and the common priesthood of the faithful, arising from the place which confirmation holds within the process of Christian initiation as presented in universal magisterial documents. If Czech and Slovak dioceses make a point about an effective pastoral practice, they should recognise the foundation laid by the Second Vatican Council and the following magisterial documents. Emphasising the visible complementarity and continuity of the three sacraments of Christian initiation opens the door to a deeper understanding of the sacrament of confirmation as well as acceptance of the common priesthood as the vital aspect of Christian existence by the faithful.

Catholic Theological Faculty, Charles University

Thákurova 3

16000 Praha 6

E-mail: matisovska@ktf.cuni.cz

52 Benoît-Dominique de La Soujeole compares a participation on the sacrifice of the Eucharist arising from the common priesthood with the participation arising from the ministerial priesthood. Lay people are engaged in a twofold manner - they take part in the action of the ordained servant who makes sacramentally present the unique sacrifice of Christ joined by the sacrifice of the Church (difference in degree) and they also bring themselves as a sacrifice (difference in essence). Cf. Benoît-Dominique de La Soujeole, 'Doktrinálni základy kněžské spirituality,' Salve 20, no. 2 (2010): 115-123. I believe that it might correspond with the two stages of participation in Christ's priesthood constituted by the sacramental characters conferred in baptism and confirmation. 